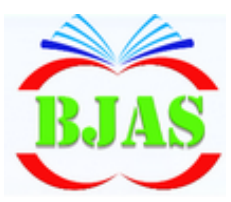

ISSN $1814-5868$
Available online at: http//bjas.bajas.edu.iq

College of Agriculture, University of Basrah

DOi:10.21276/basjas

\title{
The Effectiveness of Genistein on Early Puberty of the Arabi Female Lambs: The Concentration of Sex Hormones and Development of Reproductive Organs
}

\author{
Maysaa M. A. Al-Rsitmawi ${ }^{1}$ \& Waleed Y. Kassim ${ }^{2 *}$ \\ 'Department of Animal Production, College of Agriculture, University of Misaan, Iraq \\ ${ }^{2}$ Department of Animal Production, College of Agriculture, University of Basrah, Iraq \\ *Corresponding author e-mail: waleedyosif0@gmail.com
}

Received 15 March 2019; Accepted 24 May 2019; Available online 4 September 2019

\begin{abstract}
This study was undertaken at special sheep farm in Missan province. The study began at the 1st of September 2016 and ended at the 29th of December 2016. Sixteen female Arabi lambs, with an average age $210 \pm 5$ days, and average body weight (23.88) Kg, were randomly divided into four groups as follows:. T1 as a control group, T2 treated with a dose of $0.5 \mathrm{~g}$ genistein.head $^{-1}$, T3 treated with a dose of $1 \mathrm{~g}$ genistein.head $^{-1}$. T4 treated with a dose of $2 \mathrm{~g}$ genistein.head ${ }^{-1}$. All treatments were given genistein orally three times a week to investigate the effect of genistein treatment on sex hormones and reproductive organ development. The results showed significant $(\mathrm{P}<0.05)$ increase in concentrations of sex hormones (FSH, LH and estrogen) in female lambs treated $1 \mathrm{~g}$ genistein for three times a week compared with control, T2 and T4 during the whole study period. The weights of the uterus, right ovary and ovary duct length of T3 group increased significantly $(\mathrm{P}<0.05)$ in comparison with TI group. There were no significant $(\mathrm{P}<0.05)$ differences observed between treated groups in left ovary weight. Treated of Arabi female lambs with different levels of genistein improved the development of uterus during puberty.
\end{abstract}

Keywords: Fertility traits, Polymorphism, sheep, TGF-B gene.

\section{Introduction}

Sheep production depends on the reproductive trails such as the function of ovaries, sex hormones secretion, the ability of ewes to mate, pregnant, lactating and caring their lambs. The attempt to improve the reproductive efficiency is the major step for farms, especially in countries depend mainly on agriculture (Ibarra et al., 2000). There are many ways to improve the reproductive efficiency, such as, artificial insemination, genetics, embryo transfer and hormone treatment (Patton, 2012).

Genistein is a phytoestrogen belong to isoflavones compounds, which derived and found in natural plant such as soya bean, alfalfa and clover (Elizabeth et al., 2007). Genistein may affect the chemical structure of muscle, bone, blood and milk for many 


\section{Al-Rsitmawi \& Kasim / Basrah J. Agric. Sci., 32 (Special Issue): 1-7, 2019}

animals (King et al., 1998). The phytoestrogen is playing a role in regulating the reproductive system function because it has the similar action of natural estrogen in the body (Anderson et al., 2002).

Genistein can activate and attach with both Alpha and/or Beta estrogen- receptors, in cells membrane (Kuipere et al., 1998; Clarke et al., 2010). Genistein had the same phenol ring that present in natural estrogen (Turner et al., 2007). Christos et al., (2006) reported that the phytoestrogens compounds could effect on reproductive tract through stimulating the hypothalamus gland to release the gonadotropin releasing hormone (GnRH). Izabela et al. (2013) suggested that genistein is hydrated by the rumen micro-organism to P.ethel phenol, which affect the activity of ovary and uterus. According to Griffth, (2012) who suggested that fed isoflavones or treatment female lambs with different levels of genistein led to stimulate the gonad glands and early puberty with low body weight.

The purpose of this study was to determine the effect of genistein treatment on sex hormone concentrations and reproductive organ development in Arabi female lambs.

\section{Materials \& Methods}

This study was carried out in the a private field in Missan province. It began at the $1^{\text {st }}$ of September 2016 and ended at the $29^{\text {th }}$ of December 2016 Sixteen female Arabi lambs, with an average age $210 \pm 5$ days, and average body weight $23.88 \mathrm{Kg}$, were randomly divided into four groups as follows:. T1 as a control group (without any dosage of genistein). T2 treated with $0.5 \mathrm{~g}$ genistein. head $^{-1}$ (Soy-Free Genistein product by the Sopbora Japonica Company as powder). T3 treated with $1 \mathrm{~g}$ genistein.head ${ }^{-1}$. T4 treated with $2 \mathrm{~g}$ genistein.head ${ }^{-1}$ orally. Genistein doses were given three times a week. All animals were fed $2 \%$ of body weight barley daily during morning and evening at 7 a.m. and 2 p.m. respectively. The amount of feed provided adjusted weekly according to the new weights. After 15 days of genistein treatment, the rams were introduced to detect $1^{\text {st }}$ estrus. Blood samples were taken monthly to determine sex hormone levels. Three animals were slaughtered from each treatment after reaching the age of puberty to determine the weights of reproductive organs such as uterus, right ovary, left ovary and ovary duct length. Also, samples from uterus were taken and kept in plastic containers, including $10 \%$ formalin for 24 hours, and then transported to the laboratory of Veterinary College, University of Basrah to study the development of the uterus tissue according to method of Luna (1968) by using Microtome (made in China).

Ten $\mathrm{ml}$ of blood was collected monthly from all animals from the jugular vein and put in a plastic tube without anticoagulants. Blood samples were separated by centrifugation at $3000 \mathrm{rpm}$ for 15 minutes. All serum samples were frozen under $-20{ }^{\circ} \mathrm{C}$ until analysis time. FSH, LH and estrogen concentrations were determined by using a procedure associated with the kit of Monobind Inc. Company.

The obtained data were analyzed statistically using Completely Randomized Design (CRD). The significant differences were tested by Revised Least Significant Differences (RLSD) at the $\mathrm{P}<0.05$ levels of significance by using the program of SPSS (2012). 


\section{Al-Rsitmawi \& Kasim / Basrah J. Agric. Sci., 32 (Special Issue): 1-7, 2019}

\section{Results}

Table (1) explained the effect of genistein treatment on sex hormone concentrations in Arabi female lamb`s blood. The concentrations of FSH, LH and estrogen hormones of T3 increased significantly $(\mathrm{P}<0.05)$ compared with other groups during all months. On the other hand, no significant differences were presented between $\mathrm{T} 2$ and T4 especially during second and third months.
Table (2) exhibited the effect of different levels of genisteinon some reproductive organs in Arabi female lambs. The weights of the uterus, right ovary and ovary duct length of T3 lambs increased significantly $(\mathrm{P}<0.05)$ in comparison with those of TI group. While, there is no significant $(\mathrm{P}<0.05)$ differences were observed between treated groups in left ovary weight except in T3. However, the right ovary was higher in weight compared with the left one.

Table (1): The effect of different levels of genistein on sex hormone concentrations in serum of Arabi female lambs (Mean $\pm \mathrm{SE}$ )*.

\begin{tabular}{|c|c|c|c|c|c|}
\hline \multirow[b]{2}{*}{ Hormone } & \multirow[t]{2}{*}{ Months } & \multicolumn{4}{|c|}{ Groups (Treatments) } \\
\hline & & T1 & $\mathrm{T} 2$ & T3 & $\mathrm{T} 4$ \\
\hline \multirow[t]{3}{*}{ FSH (ng. ml ${ }^{-1}$ ) } & First & $0.33^{\mathrm{c}} \pm 0.05$ & $0.58^{\mathrm{b}} \pm 0.06$ & $0.76^{\mathrm{a}} \pm 0.09$ & $0.56^{\mathrm{b}} \pm 0.08$ \\
\hline & Second & $1.06^{\mathrm{b}} \pm 0.38$ & $1.43^{\mathrm{b}} \pm 0.30$ & $2.88^{\mathrm{a}} \pm 0.52$ & $1.34^{\mathrm{b}} \pm 0.52$ \\
\hline & Third & $1.90^{\mathrm{b}} \pm 0.12$ & $2.04^{\mathrm{ab}} \pm 0.53$ & $2.99^{\mathrm{a}} \pm 0.43$ & $2.29^{\mathrm{a}} \pm 0.42$ \\
\hline \multirow[t]{2}{*}{ Mean } & & $1.12^{\mathrm{b}} \pm 0.18$ & $1.35^{\mathrm{b}} \pm 0.21$ & $2.21^{\mathrm{a}} \pm 0.22$ & $1.40^{\mathrm{b}} \pm 0.86$ \\
\hline & First & $1.13^{\mathrm{c}} \pm 0.29$ & $1.30^{\mathrm{bc}} \pm 0.28$ & $2.13^{\mathrm{a}} \pm 0.42$ & $1.77^{\mathrm{ab}} \pm 0.24$ \\
\hline \multirow[t]{2}{*}{ LH (ng.ml $\left.{ }^{-1}\right)$} & Second & $2.66^{\mathrm{b}} \pm 0.46$ & $2.96^{\mathrm{ab}} \pm 0.47$ & $3.38^{\mathrm{a}} \pm 0.65$ & $3.53^{\mathrm{a}} \pm 0.61$ \\
\hline & Third & $2.69^{\mathrm{b}} \pm 0.46$ & $3.65^{\mathrm{a}} \pm 0.72$ & $4.11^{\mathrm{a}} \pm 0.54$ & $3.61^{\mathrm{a}} \pm 0.11$ \\
\hline Mean & & $2.16^{\mathrm{c}} \pm 0.40$ & $2.63^{b c} \pm 0.492$ & $3.20^{\mathrm{a}} \pm 0.41$ & $2.91^{\mathrm{b}} \pm 0.32$ \\
\hline \multirow[t]{3}{*}{ Estrogen (pg.ml ${ }^{-1}$ ) } & First & $20.01^{\mathrm{b}} \pm 1.70$ & $25.04^{\mathrm{a}} \pm 2.49$ & $25.60^{\mathrm{a}} \pm 3.66$ & $20.69^{b} \pm 3.46$ \\
\hline & Second & $21.01^{\mathrm{b}} \pm 2.89$ & $25.17^{\mathrm{ab}} \pm 3.70$ & $29.82^{\mathrm{a}} \pm 2.24$ & $25.92^{\mathrm{ab}} \pm 3.60$ \\
\hline & Third & $25.53^{\mathrm{c}} \pm 2.57$ & $28.32^{\mathrm{bc}} \pm 3.00$ & $39.48^{\mathrm{a}} \pm 2.89$ & $31.88^{\mathrm{b}} \pm 3.35$ \\
\hline Mean & & $22.25^{\mathrm{c}} \pm 2.40$ & $26.18^{\mathrm{b}} \pm 3.06$ & $31.63^{\mathrm{a}} \pm 2.26$ & $26.16^{\mathrm{b}} \pm 3.47$ \\
\hline Mean & & $22.25^{\mathrm{c}} \pm 2.40$ & $26.18^{b} \pm 3.06$ & $31.63^{\mathrm{a}} \pm 2.26$ & $26.16^{\mathrm{b}} \pm 3.47$ \\
\hline
\end{tabular}

*Different small letter within each row mean significantly differ $(\mathbf{p}<0.05)$.

Table (2): The effect of different levels of genistein on some reproductive organ weights (puberty, uterus, right and left ovary) in Arabi female lambs (Mean \pm SE)*.

\begin{tabular}{lccccc}
\hline \multirow{2}{*}{ Trails } & \multicolumn{5}{c}{ Groups } \\
\cline { 2 - 6 } & No. & T1 & T2 & T3 & T4 \\
\hline Puberty weight $(\mathrm{kg})$ & 3 & $33.97^{\mathrm{c}} \pm 2.09$ & $35.41^{\mathrm{b}} \pm 1.96$ & $38.12^{\mathrm{a}} \pm 0.94$ & $37.08^{\mathrm{ab}} \pm 0.83$ \\
\hline Uterus weight $(\mathrm{g})$ & 3 & $10.94^{\mathrm{b}} \pm 1.11$ & $12.45^{\mathrm{b}} \pm 1.14$ & $17.97^{\mathrm{a}} \pm 1.95$ & $15.69^{\mathrm{a}} \pm 1.23$ \\
\hline Right ovary weight $(\mathrm{g})$ & 3 & $0.49^{\mathrm{b}} \pm 0.01$ & $0.52^{\mathrm{b}} \pm 0.02$ & $0.65^{\mathrm{a}} \pm 0.01$ & $0.55^{\mathrm{b}} \pm 0.01$ \\
\hline Left ovary weight $(\mathrm{g})$ & 3 & $0.29^{\mathrm{b}} \pm 0.01$ & $0.48^{\mathrm{a}} \pm 0.03$ & $0.32^{\mathrm{b}} \pm 0.02$ & $0.41^{\mathrm{a}} \pm 0.02$ \\
\hline Ovary duct length $(\mathrm{cm})$ & 3 & $13.0^{\mathrm{b}} \pm 0.99$ & $17.0^{\mathrm{a}} \pm 0.81$ & $17.5^{\mathrm{a}} \pm 1.52$ & $13.5^{\mathrm{b}} \pm 1.11$ \\
\hline
\end{tabular}

*Different small letter within each row mean significantly differ $(\mathbf{p}<0.05)$.

Plate (1) displayed a histological section of female uterus of control group (T1). The uterine gland glands were circular, small, non-mature, resided in limit areas of the uterus inlay and so far from the epithelium layer of the uterus cavity with a normal 


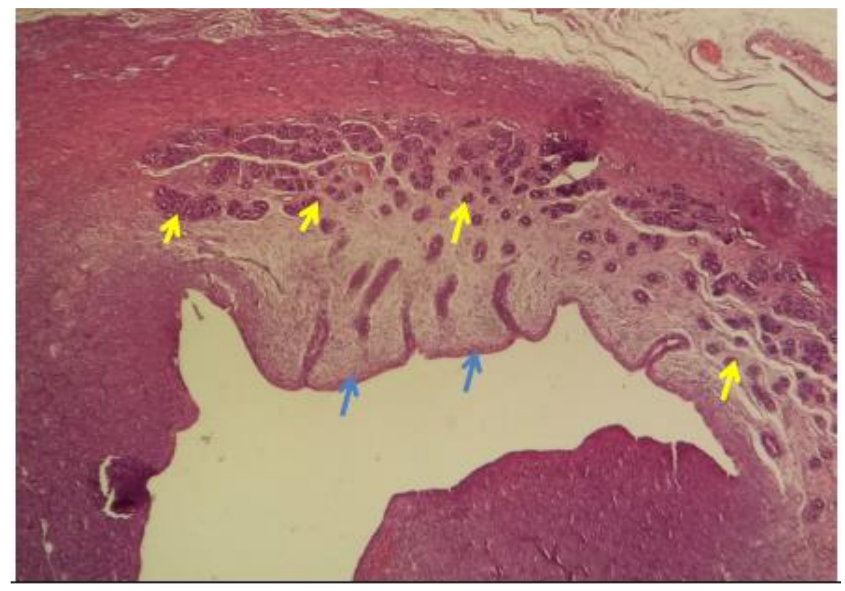

Plate (1): Anatomic section of female uterus of animal in control group (T1). The mucosa glands (yellow arrows) were circular, smallest, nonmature, receded in limit areas of the uterus inlay and so far from the epithelium layer (blue arrows) of the uterus cavity with a normal number $(\mathrm{H} \& \mathrm{E}$, 40x.).

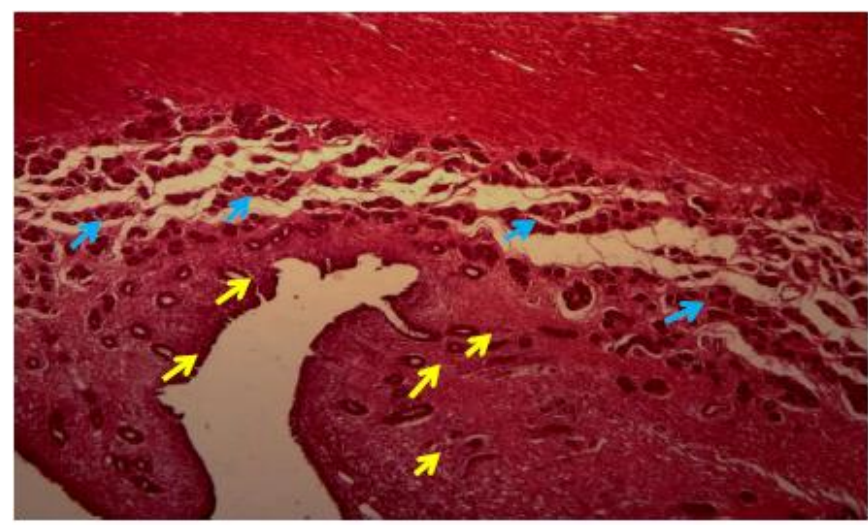

Plate (3): Anatomic section of female uterus of animal in $\mathrm{T} 3$ group. An increase in the number of mucosa glands (yellow arrows) and diffusion overall areas of uterus inlay and its more attachment with the epithelium layer (blue arrows) of uterus cavity (H \& E, 40x).

number. Also, those glands covered by cells that did not arrive to the mucus secretion phase. While, the uterine gland of T2 animals were active, bigger, taller, diffusion on more places in uterus inlay and nearer to the epithelium layer of the uterus cavity compare with control group (Plate 2).

There is an increase in the number of the mucus glands in animals of T3 and T4 groups (Plate $3 \& 4$ respectively). Those glands seem

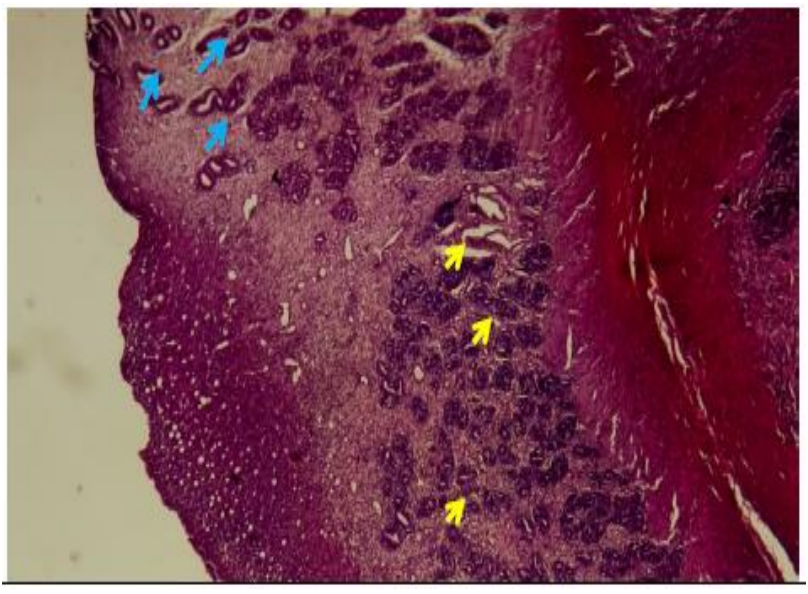

Plate (2): Anatomic section of female uterus of animal in T2. The mucosa glands (yellow arrows) of animals in $\mathrm{T} 2$ were active, bigger, taller, diffusion on more places in uterus inlay and nearer to the epithelium layer (blue arrows) of the uterus cavity (H \& $\mathbf{E}, 40 x$.).

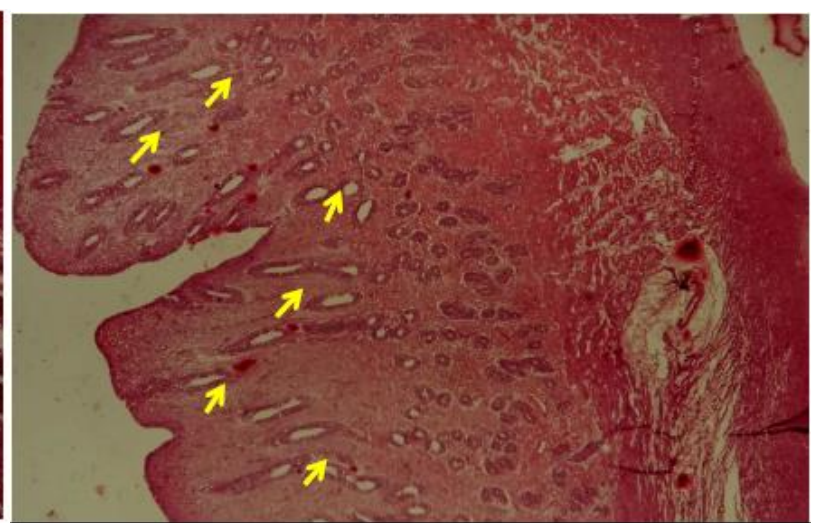

Plate (4): Anatomic section of female uterus of animal in T4 group. There is an increase in the number of mucosa glands (yellow arrows), those glands seem to be diffusion overall areas of uterus inlay and biggest, tallest and widest compared with anther groups $(\mathrm{H} \& \mathrm{E}, 40 \mathrm{x})$.

to be diffused over all areas of uterus inlay and biggest, tallest, widest and more attachment with the surface of the uterus cavity in comparison with $\mathrm{T} 1$ and $\mathrm{T} 2$ groups.

\section{Discussion}

The increase in the concentration of FSH and LH may due to that genistein stimulate gonadotropin releasing hormone GnRH from hypothalamus gland or may stimulate 
estrogen- receptors because of the genistein when binding with those receptors will active the cyclic protein kinase (AMP) (Skinner \& Dufourny, 2005). This result agrees with the results of Wojcik et al., (2006). While, the increase of LH concentration of T3 group related to the effect of genistein (like estrogen) through the elevation of positive estradiol feedback (Baratta et al., 2001), because of the genistein has the same function of natural estrogen in the body (Turner et al., 2007), so, unlikely that genistein causes any negative feedback on LH secretion. Genistein has ability to conjure up and calling the GnRH, which led to increases the $\mathrm{LH}$ secretion during the high wave of LH in ewes (Romanowicz et al., 2004). This result was similar to that found by Polkowska et al. (2004). Furthermore, the isoflavones have an intimacy to attachment with estrogen receptors in both ovary and hypothalamus gland (Kuiper et al., 1998) and caused an effect on enzymatic estradiol production (Wojcik et al., 2006), this may be a reason for the elevation of estrogen concentration in the treated groups compared with control once. Our result agreed with the results of Griffith (2012) who found an increase in estrogen concentration after feeding female lamb's soya bean (isoflavone).

The weights of the uterus, right ovary and ovary duct length of T3 animals increased significantly $(\mathrm{P}<0.05)$ in comparison with the TI group (Table 2), may due to that of T3 animals have higher weight at puberty, which reflected positively on the general body growth including reproductive organs (Hafez \& Hafez, 2000). Or may due to that the similarity between genistein and estrogen, because they had the same structure and functions, on the smooth uterus tissues through stimulating the receptors of reproductive organ cells membrane and share in synthesis of proteins thus play an important role in uterus gland growth (Buerj, 2014). Whereas, Clapper \& Paulson (2015) reported another reason that phytoestrogen increase the weight of the smooth muscles especially those belongs to the uterus and ovaries. A similar result was also observed by Mustonen (2015) and Izabela et al. (2013), they were recorded an increase in uterus weight of animals treated with phytoestrogens. However, the right ovary was higher in weight compared with the left one, because of the right one is more active than left once (Lawson, 2011). T3 animals showed more development in the uterus gland as compared with the control group, may be due to the increase in puberty weight and estrogen concentration in T3 female lambs (Table 1), as known, estrogen plays important role in the growth and development female tract (Thibault et al., 1993).

\section{Conclusions}

From our results, we concluded that treating Arabi female lambs with $1 \mathrm{~g}$ genistein.head ${ }^{-1}$ orally at three times a week caused an increase in the puberty weight and concentrations of FSH, LH and estrogen hormone (shortening age at puberty). Also, treated genistein at dose $1 \mathrm{~g}$.head ${ }^{-1}$ elevate the activation of reproductive organ such as the uterus and ovaries.

\section{Acknowledgements}

The authors would like to thank the people who are working in the Animal Field and the scientific laboratories for their assistance in research.

Conflict of interest: The authors declare that they have no conflict of interest.

Ethical approval: all applicable national and international guidelines for the care and use of animals were followed. 


\section{References}

Anderson, G.M.; Connors, J.M.; Hardly, S.L. \& Goodman, R.L. (2002). Thyroid hormone mediates steroid-independent seasonal changes in luteinizing hormone pulsatile in the ewe. Biol. Repoed., 66(3): 701-706.

Baratta, M.; West, L.A.; Trujillo, A.M. \& Nett, T.M. (2001). Active modulates differential effect of estrogen on synthesis and secretion of follicle stimulation hormone in ovine pituitary cells. Biol. Reprod., 64(2): 714-719.

Buerj, K. (2014). Genisten, Supplement phytoestrogen and isoflavon health benefit dosage and review of side effects. Book now for unforgettable views of Dubai: 212pp.

Christos, A.S.; Tsatsanis, C.; Gravanis, A. \& Margioris, A.N. (2006). Corticotrophinreleasing hormone augments proinflammatory cytokine production from macrophages in vitro and in lip polysaccharide-induced endotoxin shock in mice. Infect Immun., 70(11): 6068-6074.

Clapper, J. \& Paulson, C. (2015). Effect of Short term administration of genistein on hypothalamus and anterior pituitary hormone in ovariectomized gilts. J. Anim. Sci., 5(2): 163-173.

Clarke, I.J.; Cummins, J.T. \& Crowder, M.E. (2010). Long-team negative feedback effects of estrogen and progesterone on the pituitary gland. J. Endocrinol., 120(2): 207-214.

Elizabeth, J.Z.; Ming, N.G. \& Kathy, Q.L. (2007). Extraction and purification of Is flavones from soybeans and characterization of their estrogenic activities. J. Agric. Food Chem., 55(17): 6940-6950.
Griffth., J.K. (2012). Effects of soy isoflavones on the attainment of puberty and breeding season in Suffolk, duration of the Rambouillet, ewe lambs,. M. Sc. Thesis, Faculty of the Graduate School of Angelo State Univ.: 51pp.

Hafez., B. \& Hafez., E. (2000). Reproduction in Farm Animal. $7^{\text {th }}$ ed. Inc. Wilkins, Philadelphia: 315pp.

Izabela, W.; Bawek, P.; Chiara, M. \& Dorota, B. (2013). Diverse effects of phytoestrogens on the reproductive performance: Cow as a model Int. J. Endocrinol., 3(1): 1-15.

Ibarra, D.D.; Laborde, D.A. \& Van-Lier, E.S. (2000). Repeatability relationship with field mating performance of a serving capacity in rams. Small Rumin. Res., 37(1): 156-169.

King, R.A.; Mono, M.M. \& Head, R.J. (1998). Assessment of isoflavonoid concentrations in Australian bovine milk samples. J. Dairy Res., 65(3): 479-489.

Kuipere, G.G.; Lemmen, J.G.; Carlson, B.J.G.; Safe, S.H.; Van der Saag, P. T.; Burg, B. \& Gustafson, J.A. (1998). Interaction of estrogenic chemicals and phytoestrogens with estrogen receptor $\beta$ (Beta). Endocrinol., 139(10): 4252-4263.

Lawson, J.R. (2011). Anatomy and Physiology of Farm Animals. Platypus Global Media, New Zealand: 244pp.

Luna, L.G. (1968). Manual of Histological Staining Method of the Armed Forces. Institute of Pathology Paperback, $3^{\text {rd }}$; Mc .Grow -Hi 11 Book Co In C., New York: 255pp.

Mustonen, E. (2015). Red clover isoflavonoids in feed, plasma and milk of ruminants. Doct. Prog. Clin. Vet. Med.. Univ. Helsinki. 60pp. 
Patton, T.A. (2012). Effect of isoflavones interpretive functions of ram lambs, M. Sc. Thesis. Univ. Angelo state: 27pp.

Polkowska, J.; Yvonne, R.; Marta, W.; Katarzyna, R.; Tomasz, M. \& Adrzejmade, M. (2004). Effects of intracerebroventricular infusion of genistein on gonadotropin subunit mRNA and immunore activity of gonadotrophins and estrogen receptor in the pituitary cell of the anoestrous ewe. J. Chem. Neur., 28(4): 217-224.

Romanowicz, K.; Misztal, T. \& Barcikowsk, I.B. (2004). Genistein, a phytoestrogen, effectively modulates luteinizing hormone and prolactin secretion in ovariectomized ewes during seasonal anestrus. J. Neur., 79(2): 73-81.

Skinner, D.C. \& Dufourny, L. (2005). Estrogen receptor B. immunno reactive neurons in ovine hypothalamus distribution and colocalisation with gonadotrophin releasing hormone. J. Neur., 17(1): 29-39.

SPSS. (2012). Statically package for social science, version 16 user's guide for statistical, Chicago.

Thibault, C.; Levasseur, M. \& Hunter, R. (1993). Reproduction in Mammals and Man. Paris: Ellipses: 800pp.

Turner, J.V.; Agatonovic-Kustrin, S. \& Glass, B.D. (2007). Molecular aspects of phytoestrogen selective binding at estrogen receptors. J. Pharm Sci., 96(8): 1879-85.

Wojcik, G.A.; Romanowicz, K.; Misztal, T. \& Polkowska, J. (2006). Estrogen -like effect of genistein on follicle stimulating hormone release in ovariectomized ewes. J. Anim. Feed Sci., 15(4): 576-589. 